\title{
THE SHIFTING OF VILLAGE AUTONOMY CONCEPT IN INDONESIA
}

\begin{abstract}
This research tries to examine comprehensively about the different concepts about village autonomy in Law No. 5 of 1979 and Law No. 6 of 2014. The results supposed to be contributed as scientific journal and other scientific work, which is valuable for scientific improvement in provincial autonomy law. Itsurely could be used by the local governments in Indonesia and hopefully in Asia as a framework to construct a strategic procedure of the village development. This study uses the conceptual approach and analysis approach as methods. The conceptual approach directed to examine the first legal issue related to differ autonomy concept in Law No. 5 of 1979 and Law No. 6 of 2014 while the analytical approach is used for assessing the alignment of the concept of village autonomy in Law No. 6 of 2014 with a constitutional mandate. The results found, there is improvements in the draft of Law No. 6 Year 2014 by increasing the funding source for the village, and guarantee the right to determine her village. A village, in Law No. 6 Year 2014, is possible to switch into a custom village.
\end{abstract}

Keywords: village, village governance, village autonomy

\section{Introduction}

Enactment of the Law No. 6 Year 2014, constantly ended the village government setting in Law No. 32 Year 2004, ${ }^{1}$ and a sign of the village model setting within a different law. Such condition had ever occurred in the New Order era by the emerging of Law No. 5 Year 1979 on Village ("Village Law"). This concept of Village Government may cause a lot of problems such as weakening the capacity of the village administration, policy form and the village unique ${ }^{2}$. The problems that occurred in the Village Law is connected to the condition in the New Order era that is centralistic. Condition that is legally different from the style of reform era nowday. In addition, the differences in socio-political background do not guarantee that the Law No. 6 Year 2014 has a better quality of regulation due to the political interests of the maker. ${ }^{3}$

Later, after an issuance of the Law No. 6, 2014, the resistance emerged from many customary law societies. They consider it is a mono-culture that may damage the future of customary law society. This rejection is considered as the cause of why the Village Lawhad been changed into Law No. 22 Year 1999 about the Local Government.

There are two main problems that will be answered through this article. The first is about the issue related to construe of conceptual village autonomy that contained in and Law No. 6 Year 2014, the second is about the issue related to conceptual differences of Village Government in those two regulation.

\footnotetext{
${ }^{1}$ Indonesia, Undang-Undang tentang Desa (Law regarding Village), UU No. 6 Tahun 2014, LN No. 7 Tahun 2014 (Law Number 6 Year 2014, SG No. 7 Year 2014). Art. 121.

2 Emanuel Sujatmoko, "Pembagian Kekuasaan Secara Vertikal," Yuridika 20, Number. 1 (2005).

3 "Kades Desak Alokasi APBN Untuk Desa Segera Disahkan," Www. Jppn.com, 2013, http://www.jpnn.com/read/2013/12/18/206361/Kades-Desak-Alokasi-APBN-Untuk-Desa-segera-Disahkan-. Accessed 25 April 2016.
} 


\section{Village Autonomy}

The word autonomy first interpreted from Dutch language autonomie, comprising two syllables, these are auto means single, and nomoi means law. Related to that source, autonomy could be interpreted as the self-governing ${ }^{4}$.

The construction of autonomy stated by Kartohardikoesoemo ${ }^{5}$ widely interpret in many perspectives. Not only about government, but also the social-culture and their beliefs. Soetardjo also states that conceive village autonomy made by the Netherland limits explain of village autonomy itself. The meaning that is not well-known even among the village people as a customary law society before the Netherland landed in Indonesia.

The concept of village autonomy is referred to the concept of district autonomy as stated in the Law No. 32 Year $2004^{6}$. Thus, we can conclude that define village autonomy concept is the authority, power and obligation of the autonomous region for governing their own region, related to their origin and custom in the system of Unitary Republic of Indonesia.

\section{A. The Concept of Village Autonomy in Village Law regarding Village Government}

The constitutional background that covers the system setting of village autonomy in Village Law regarding Village Government is listed in the Article 18 of The 1945 Constitution of The State of The Republic of Indonesia (pre-amendment), stated as ${ }^{7}$ :

"The division of the territory of Indonesia into large and small regions shall be prescribed by law in consideration of and with due regard to the principles of deliberation in the government system and the hereditary rights of special territories."

The existence of the village is associated with the state recognition of their right to the origin that attached to the units' area in Indonesia. Such recognition is reinforced through the Article 18 explanation, which states that ${ }^{8}$ :

"In the territory of Indonesia there are approximately 250 self-governing regions (zelfbesturende landschappen) and village communities (volksgemeeschappen), such as the "desa" (village) in Java and Bali, the "nagari" in Minangkabau, the "dusun" and "marga" in Palembang and other social-adminstrative units. These regional units have their own indigenous social systems and thus may be considered as special regions. The Republic of Indonesia respects the status of the special regions and any government regulation on these regions shall have due regard to their hereditary rights."

Because of there is no explicit definition of village conception in Village Law, to interpret village autonomy in that law, could not be separated from the the autonomous regions that listed in the Law No. 5 Year 1974 regarding Local Government. Therefore, to construe

\footnotetext{
${ }^{4}$ Bayu Suryaningrat, Pemerintahan Administrasi Desa Dan Kelurahan, 4th ed. (Jakarta: Rineka Cipta, 1992),p. 141.

${ }^{5}$ Soetardjo Kartohadikoesoemo, Desa, 1st ed. (Jakarta: Balai Pustaka, 1984),p. 212.

${ }^{6}$ Indonesia, Undang-Undang tentang Pemerintahan Daerah (Law regarding Local Government), UU No. 32 Tahun 2004, LN No. 125 Tahun 2004 (Law Number 32 Year 2004, SG No. 125 Year 2004). Art. 1.

${ }^{7}$ Unofficial english translation from http://www.wipo.int/edocs/lexdocs/laws/en/id/id048en.pdf

8 ibid.
} 
village autonomy is depended on the concept of District autonomy and autonomous regions that listed in Law of Local Government. District autonomy as interpreted in Article 1 letter c of Law No. 5 Year 1974 is " "... the authority, power and obligation to govern their own household related to the valid legislation." whereas on Article 1 letter e, stated "Autonomous region that recently known as District is the law societies that have certain border areas that are entitled, allowed and obliged to govern their own household around Unitary Republic of Indonesia (NKRI) and oriented to the valid legislation."

Related to those two stated definitions, we could conclude that District autonomy is the authority, power and obligation to govern their own household that could be done only by the autonomous region. Thus, determine to article states above, that there are two scopes of autonomous region, those are the Daerah Tingkat I and Daerah Tingkat II ${ }^{10}$ which focusing on the District autonomy in the Daerah Tingkat II with the assumption that this Daerah Tingkat II is directly closer to the factual society's problem. Daerah Tingkat I, in this case is a province whereas Daerah Tingkat II is a Kabupaten/City. As stated in the law, the village position may not be included in autonomous regions' category that authorize to govern their household independently. Beyond that, it doesn't mean that village is not categorized as an autonomous region and not entitled to autonomy.

Determination of village's position as the autonomous region depends on Article 88 of District Law, which state that all the things of village is organized and made up in a law that particularly sets the village's system. That determination policy is set as a basis of the enactment of Village Law (UU Desa) in Indonesia. Village as stated in the Village Law is differed from Kelurahan. In Article 1 letter a, Village is defined as:

"An area lived by several people as unite community, including community unit of law which has the lowest administration organization and controlled by the Head (Camat) and the right to conduct its own activities in Negara KesatuanRepublik Indonesia."

Under these provisions, it could be concluded that Village is also an autonomous region like the local Level I and Level-II that authorize to conduct its own activities. Village Act on Village Law is set as an ordinary village community unit and as a traditional community unit, which are uniformly characterized by: ${ }^{11}$

1) Has legal name;

2) Has certain number of village people, living harmoniously;

3) Has regions remain within certain constraints;

4) There are certain territories that have legal borders;

5) There is an elected Chief of Village or lurah;

6) Village is the smallest part of the Indonesian administration system;

7) It is an autonomous so it ability to govern its own activities;

\footnotetext{
${ }^{9}$ Author Translation

${ }^{10}$ General Explanation of Indonesia, Law No. 5 Year 1974, 1974."Regions are formed based on the principle of decentralization called Autonomous Region, afterward, called 'Regional', which in this Act known as the Daerah Tingkat I and Daerah Tingkat II "...In order to improve service to the community and the implementation of development, the law is putting the emphasis on the autonomy of the Daerah Tingkat II, with the consideration that the Daerah Tingkat II is directly connected to the public that is expected to understand better and meet the aspirations of the people." (Author Translation)

${ }^{11}$ Jimly Asshiddiqie, Gagasan Konstitusi Sosial: Institusionalisasi Dan Konstitusionalisasi Kehidupan Sosial Masyarakat Madani, 1st ed. (Jakarta: LP3ES, 2015). Page. 349.
} 
8) Owning many resources in both economic and non-economic;and

9) Having a legal law reference written or marked by citizens and government officers of the village.

The clause of Article 1 letter a, also confirms view of the village in the structure of the country, and the clause "the lowest of the administration led by the Chief-Camat" has placed the status of the village as the lowest administration of the country, thus, construe of village autonomy as an autonomous region is as part of Daerah Tingkat II autonomy. That construction has implications in village autonomy, the broad authority of village autonomy is not only associated with the authority attached to the village as a socio-cultural entity, but also includes the authority granted by the local government to carry out functions of public administration and social services ${ }^{12}$.

The most fundamental issues related to the construction of village autonomy in Village Law is the absence of a affirming clause of the autonomy of authority (government) in the village for governing their activities related to rural domestic affairs. Even though the law also does not provide a clear definition about that. The authority of village autonomy within Village Law is attached to the Chief of Village ability and the highest authority in charge of the village ${ }^{13}$ governance, as contained in Article 10 Paragraph (1) that stated as: ${ }^{14}$

"Chief of Village is running the rights, powers and obligations of the leadership of the village for conducting its own domestic, and an organizer and primary responsibility in the areas of governance and community development. In affairs of the village government, government affairs public, including the development of peace and order under the regulations, applicable and develops a spirit of mutual help as the major joints of implementing the village government."

Beyond the clauses of Article 10 Paragraph (1), the rural household affairs under ability village autonomy covering at least three (3) main matters: first, government affairs regarding to the village government administer; second, the development affairs, which is related to manage rural development programs both from governmental organizations, and those funded by coadministration; and third, the public affairs in the course of the village government affairs, public government affairs, including fostering peace and public order.

Besides, some matters related to exist Village Head, there are still matters that technically submittedto the village and is associated with the village authority to implement the Village Head Election (Pilkades) in Article 5 of Law No.. 5, 1979 ${ }^{15}$. The authority related to Village Head Election is non exsistent, because the policy related to the Chief of Village election (Pilkades)mechanisms, been determined by the superstructure of the village.One thing is the same as establish the structure of village government were also hung on establish Regional Regulation / city. Related to village autonomy, TaliziduhuNdrahaargues that there are domestic affairs of the village at the time of the Law No. 5Year 1979are essential, namely: ${ }^{16}$

\footnotetext{
${ }^{12}$ Suryaningrat, Pemerintahan Administrasi Desa Dan Kelurahan. Page. 141-142.

${ }^{13} \mathrm{Ni}$ 'matul Huda, Hukum Pemerintahan Desa Dalam Konstitusi Indonesia Sejak Kemerdekaan Hingga Era Reformasi, 1st ed. (Malang: Setara Press, 2015). Page. 148.

${ }^{14}$ Indonesia, Law Number 5 Year 1979 on Village Government, 1979. (author translation)

${ }^{15}$ Article 5 paragraph(2).

${ }^{16}$ Hanif Nurcholis, Pertumbuhan Dan Penyelenggaraan Pemerintahan Desa (Jakarta: Penerbit Erlangga, 2011).Page. 34
} 
1) Valid customs that obeyed by Village People;

2) The land, heritage and village resources;

3) Rural Income;

4) Domestic affairs;

5) The Chief of village elected by the village people that has a function of governing;

6) The agency or entity "representative" or deliberation throughout implementing rural activities has a function of "setting".

One important statement stated by Ndraha, ${ }^{17}$ is that implementing village autonomy under Law No. 5Year 1979is more than just participatory affair. Construction of village autonomy is not separated from the unitary state paradigm of the New Order to emphasize aspects of similarity in the sense of uniformity layout of nation state. The concept of centralistic is developed in managing the centralized unitary state, systematically erode the diversity of village and customs and other social and cultural diversity.

Construction of village autonomy developed by New Order through Law No. 5, 1979, theoretically may be wrong and violate the rule of law and democracy, because formal space for the village for administering and managing the household affairs.

\section{B.Concept of Village autonomy in Law No. 6, 2014}

The concept of village autonomy in Law No. 6, 2014 should be placed upon 1945 Indonesian Constitution of Article 18B (2). Article 18B Paragraph (2) states that "The State recognizes and respects the customary law society and the rights of traditional system are all still valid and under the development of society and the principles of the NKRI, which is regulated by law". It is not made clear about the institutions that are referred as customary law community unit, but if we examine on clause explanation of Article 18 of the 1945 Constitution (pre-amendment) as an integral part of the manuscript of 1945 Indonesian Constitution (UUD 1945), the referral clause of Article 18B Paragraph (2) is Villages and reign. ${ }^{18}$

In Article 1 point (1) of Law No. 6, 2014 ${ }^{19}$, the village is defined as " a unit of community that has boundaries with the authority to regulate and manage the affairs of government, interests of the local communities based on the community's initiatives, right of origin, and / or traditional rights recognized and respected in the system of government of the Republic of Indonesia ". The formula, when juxtaposed with the concept of autonomous regions in Law No. 23, 2014 on Regional Government can be stated that the village is placed as an autonomous region, the government institution that is allowedto manage government affairs independently in certain jurisdictions, and a social entity to which the inherent cultural identity as the right of the origin and customs as instruments of governance in the region.

\footnotetext{
${ }^{17}$ Ibid.Page. 34

${ }^{18}$ Elucidation of Article 18 of Indonesia, Undang-Undang Dasar Negara Kesatuan Republik Indonesia Tahun 1945 (The 1945 Constitution of The State of Republic of Indonesia: Unofficial Translation, 1945).: "In Indonesia, approximately, there are 250 zelfbesturendelandchappendanvolksgetneenschappen State territoir, such as villages in Java and Bali, the country in Minangkabau, danmarga village in Palembang and so on. The regions that have the original order, and therefore can be regarded as a special region ... the Republic of Indonesia respects the position of those special region and all state regulations regarding the regions that will be considering the rights of the origins of the area".

${ }^{19}$ Indonesia, Law of the Republic of Indonesia Number 6 of 2014 (https://www.kemenkeu.go.id/en/Peraturan/lawrepublic-indonesia-number-6-2014, n.d.).
} 
Recognition as an autonomous region has implications conceive autonomy for the village that cannot be separated from the concept of regional autonomy in Article 1, item 6 of Law No.. 23, 2014 on Regional Government. Regional autonomy is interpreted as "the rights, powers and obligations of autonomous regions set up and manage their own administrative affairs and public interests in the system of the Republic of Indonesia". Taking a common thread between the clauses of Article 1 paragraph 1 of Law No. 6, 2014 with Article 1, item 6 of Law No. 23 In 2014, village autonomy is the autonomy owned by Village as an autonomous region which also comprises their rights, authority and responsibility. Besides, the village also has affairs sourced from co-administration or affairs of deconcentration which operate not independently exist in the village or other autonomous regions.

The position of the village as an autonomous region could also be seen through the foundation principle, underlying the regulation and governance of the village in Law No. 6, 2014. There are 13 (thirteen) village setting principles in Article 3, where ten (10) of them representing opinion the village as an autonomous region, one of them, which is the principle of admission that recognizes and respects the Ahmadiyah village as a sozio-cultural unity that is original (generic). Its meaning cannot be separated from the preceding provisions of Article 2, which stated that the basis of the Governing Village, implementation of Rural Development, Rural community development, and community empowerment village, besides Pancasila Indonesian's official philosophical foundation and the 1945 Constitution, and the Indonesian's slogan Unity in Diversity.

The benchmark to assess the quality of village autonomy is on the instrument of authority, rights and obligations is attached to the village (government and community). In the authority, the quality of village autonomy can be seen from the authority substantively grow and develop with the aspirations of the local community, both at the planning stage or in the process of implementation. Given the authority of village autonomy within Article 18 and Article 19 of Law No. 6 In 2014, it can be said that the village had a broad scope of authority, including the authority of the Government in the village, implementing Rural Development, Rural community development, and community empowerment village, which is based on the right of the origin and authority of the local village scale ${ }^{20}$.

Further provisions related to the broad authority of the village as village autonomy instrument can be seen in the Government Regulation Number 47, 2015 regarding Amendment to Government Regulation Number. 43, 2014 concerning the Implementing Regulations of Law No.. 6, 2014 concerning the village. In these regulations, there is a dichotomy associated with the village authority and the authority of customary villages. Related to the village authority that comes from the right of the origin, then Article 34 Paragraph (1) states that the village authority at least comprise:

a) The system of customary society organizations;

b) Institutional development of society;

c) Fostering institutions and customary laws;

d) Cash village land management; and

e) The development of the role of the village community.

As for the Village People, minimal authority that should be based on Article 35 of Law No. 6 of 2014 include:

\footnotetext{
${ }^{20}$ Huda, Hukum Pemerintahan Desa Dalam Konstitusi Indonesia Sejak Kemerdekaan Hingga Era Reformasi.Page. 213-215.
} 
a) Structuring the organizational and institutional systems customary society;

b) Institution customary law;

c) Ownership of customary rights;

d) Management of treasury lands customary villages;

e) Management of communal land;

f) Agreement in the lives of customary society in the village;

g) Filling the post of village head and village customs; and

h) The term of the traditional village chief.

The difference between the authority of the village and the traditional village did not happen in the authority of the village by village-scale local authority, as authority is attached to the structural duty in the village of Article 34 paragraph (2) which includes:

a) Management of boat moorings;

b) Management of Rural market;

c) The management of public baths;

d) The management of irrigation networks;

e) Management of the villagers living environment;

f) The development of public health and management of integrated health posts;

g) The development and coaching of art galleries and learning;

h) Management of village libraries and reading centers;

i) The management of village ponds;

Considering the classification and properties of matter (authorities) listed in Article 34 Paragraph (2) by considering the characteristics of the Village People generic, such authority would not be right if it should be attached to the traditional village authority. Restrictions related to set traditional village authority focus only on matters which is based on the right of the origin can be seen as an attempt to accommodate the diversity that exist in these areas.

Elements of authority also attached to the institutional structure of the village government, both to the Government of the village and the Village Consultative Body. Elements of authority attached to the Village Government under Article 26 Paragraph (2) deals with the village authority in organizing the village administration, whether in relation to the administrative procedures of the village administration, financial management and wealth of the village, and those related to the strategic policies villages to control villagers' social life.

Instruments of village autonomy besides the authority are the rights and obligations attached to the village, both on the village administration and the villagers. concerning the rights and obligations attached to the Village and the Village Community is set out in Chapter VI of Law No. 6 Year 2014. Rights (Government) Village forth in Article 67 Paragraph (1) which includes the right to:

a) Set up and manage the interests of society based on rights origin, customs, and social and cultural values Village community;

b) Establish and manage institutional Village; and

c) Obtain a source of income.

As for liabilities (Government) Village stated in Article 67 Paragraph (2) shall include the obligation to:

a) Protecting and safeguarding the unity and harmony of the village community in the framework of national harmony and unity of the Republic of Indonesia;

b) Improving the quality of life of the villagers; 
c) Developing democratic life;

d) Develop a village community empowerment; and

e) To provide and improve services to the villagers.

Examining the rights and obligations under Article 67, the instrument of rights and obligations in the Law No.. 6, 2014, is an inherent element as a marker of existence (identity) village as an institutional and social entities. If the element of authority that is attached is the recognition and authorization in the village as an institution of government, the rights and obligations are the elements of "establishment" of the village where the village is presumed to exist if the elements of the rights and obligations that exist and attached to the village. Therefore, elements of those rights and obligations are not only attached to the village, but also on the community as the co-existence of the village, as stated in Article 68 of Law No. 6, 2014.

The inherent right and marks the existence of rural communities as defined in Article 68 Paragraph (1) which includes:

a) Requiring and getting information from the village government and also overseeing the activities of the Government village, implementing Rural Development, Rural community development and empowerment of village communities;

b) To get the same service and fairness;

c) To convey the aspirations, suggestions, and opinions orally or in writing in a responsible manner on the activities of the Government village, implementing Rural Development, Rural community development and empowerment of village communities;

d) Select, selected, and / or be set to:

1) Chief of the Village;

2) The Village;

3) Members of the Village Consultative Body; or

4) Members of the village community institutions.

e) To get shelter and protection from interference peace and order in the village.

The obligations attached to the village community as stated in Article 68 Paragraph (2) includes:

a) Establish themselves and maintain Village neighborhood;

b) Encourage the creation of village activities of the Government, implementing Rural Development, Rural community development, and the village community;

c) To encourage the creation of a situation that is safe, comfortable, and at ease in the village;

d) Maintain and develop the value of deliberation, consensus, kinship, and cooperation with the Village; and

e) Take part in various activities in the village.

The rights and obligations attached to the villagers in the substantive provisions of Article 68 are pro-existence with the rights and obligations that attached to village in Article 67. Right of Villagers is an obligation for the Government of the village while the obligations inherent in the Village Community that contributed with the duties and responsibilities of village government that is existed on the authority and rights of the Village government. The derivative of the rights and obligations attached to the government and the Rural Villagers is the rights and obligations of the village authorities to implement village administration. The rights and obligations stipulated in Article 26 paragraph (3) and paragraph (4) and Article 61 of Law No. 6, 2014 which outlined the legal position relating to the village government in the management of the village government. 


\section{C.The Comparison of Village Autonomy Concept Between Law No. 5Year 1979with the Law No. 6, 2014}

Description of the two sub-chapters have already explained how to construct the conceptual of village autonomy in both laws. Generally, the concept and position of village autonomy in Law No.. 6, 2014 looks totally different from the conception of the Law No.. 5, 1979 , but what is visible on the surface does not necessarily depict the actual realities of the Act. To look objectively if there are any differences in the construction of village autonomy between the two laws, the following analysis will be done on several issues that were outlined by the two laws, namely, the first in terms of philosophy of planning policies villages and village autonomy, both of the conceptual construction of village autonomy within the provisions of article by article of each law, and the third in terms of breadth of coverage of village autonomy.

\section{Philosophy of Policy}

Philosophically, the differences between the two laws cannot be known by only recognized from the difference in the regime that underlies the existence of two of the law although it is simply agreed that the product of legislation is part of a political process that is inseparable from the character of public authorities who made it.

Construction of the power of these two laws is different. Law No. 5Year 1979created in the New Order era and considered as one of the most repressive government regimes and authoritarian in Indonesia. The repressive characters of the regime can only be seen from a local governance policy that are centralized and monocultural. The style of governance is centralized and monocultural is part of the New Order Government narrow interpretation of the concept of a unitary state. They see that, to realize an effective and efficient ${ }^{21}$ governance, the structure of the Unitary Republic of Indonesia should be a simple, homogeneous and centralized. In the village administration, policy patterns are reflected in the provisions of Article 35 of the Law No. 5, 1979, which states that:

1. Village or referred to other valid declared names through law such as kelurahan, kampung, nagari in West Sumatra, or gampong in Aceh.

2. An area occupied by a population that has the lowest administration organization led by Camat and is in the State Capital, the Provincial Capital, the Capital District, Municipal, Administrative City, and other cities that are not included in the provisions referred to in paragraph (1) expressed as the Village.

The provision is systematically implicated for the autonomy of the village, particularly related to elements of village authority, that the state does not provide enough space for the village to determine the form and structure of government, and does not recognize the principle of admission and the authority that grows based on the principle of admission, as ever the authority, rights and obligations that arise as part of the true origin of the rights attached to the village. ${ }^{22}$ Recognition of the right of the origin and customs were given to the village by category

\footnotetext{
${ }^{21}$ Considering the letter $\mathrm{b}$ stated that: "Whereas in accordance with the nature of the Unitary Republic of Indonesia, the position of the village government as far as possible be equated, by heeding the diversity of the state of the village and the provisions of the valid customs to reinforce the village government to be more capable to mobilize the people in their participation in the development and the administration of the village of widespread and effective".

${ }^{22}$ Indonesia, Law No. 5 Year 1979 on Village Government, 1979.only recognizes the authority that based on the principle of decentralization deconcentration and assistance.
} 
of customary communities that practically is ignored and forced to adapt as a government institution under the districts, so that, little by little, their existence eroded and replaced by the villages that formed by the government. ${ }^{23}$

In contrast to Law No.. 5, 1979, the construction of village autonomy in Law No.. 6, 2014 was built in the democratic regime of political power, especially with the changing character of the Indonesian constitution which already accommodates the values of the Universal Human Rights. Amendment of the Article 18 with the addition of Article 18B as well as the amendment of Article 28 with the addition of Article 28, provides confirmation related to the philosophy and style of village governance in Indonesia, that the village is recognized not only as a structure low power state, but also the legal community unit autonomous by right of origin and customs that developed in the community.

Philosophically, the presence of Article 18B actually does not change the substance of the previous Article 18, due to a clause contained in Article 18B more in an attempt to insert a clause and the content of the value contained in the explanation of Article 18 into the body of the 1945 Indonesian Constitution. The effort was related to the development of legal thought early constitutional reform. It sees that the explanation of 1945 Constitution should be abolished because the function of the explanation for the purpose Constitution in the constitutional theory is put on the statute as legislations. The addition of Article 18B is part of an effort to ensure that the substance of Article 18 of the explanation may be formally binding and the underlying arrangement of the village and the Special Region ${ }^{24}$.

Article 18B substantially acknowledged the existence of two villages, the village as smallest part of the hierarchy of state government, and the village as a unit of customary society. Construction of the village as a unit of customary law community, according to Asshiddiqie, should be placed as a non-state institution, in the sense that the law must be seen as a subject on its own or as an autonomous legal entity to manage the community's life and apart from state interference $^{25}$. The village outside the customary law communities can be mobilized for independence.

Considering that, Law No. 6 of 2014 reflects the direction of the change in Article 18B Paragraph (3) and Article 28 of the 1945 Constitution. It broadly states that the philosophical foundation protects the legislation of the existence of the customary law community unite as that has the same level of the village as the real institution that exhibits the identity of Indonesia ${ }^{26}$.

\footnotetext{
${ }^{23}$ Asshiddiqie, Gagasan Konstitusi Sosial: Institusionalisasi Dan Konstitusionalisasi Kehidupan Sosial Masyarakat Madani.Page. 350

${ }^{24}$ The substance of Article 18B clearly stated in the clauses of Article 4 of Law No. 6, 2014.For a complete analysis,read:Huda, Hukum Pemerintahan Desa Dalam Konstitusi Indonesia Sejak Kemerdekaan Hingga Era Reformasi.Page. 210-211.

${ }^{25}$ Rural communities in Indonesia can be divided between as communities and indigenous people. Customary society in Article 18B paragraph (2) of the 1945 Constitution referred to as 'Unity Law Custom Society'. The unit is called the custom society as people in the construction of customary law. Because of that, in fact, building laws that customary society can be given the status of a firm as a legal entity. So that the unity of the customary community can assume that the rights and obligations as well as acting in the traffic law as an autonomous subject. While the rural population is referred to as the legal community, as if it was deliberately intended not as an stand-alone legal subject, but is the lowest part of the organizational structure of official state".Read more: Jimly Asshiddiqie, "Konstitusi Masyarakat Desa (Piagam Tanggung Jawab Dan Hak Asasi Warga Desa)" (Jakarta, 2015). Page. 7-8.

${ }^{26}$ Considering Letter b. "That in the course of state administration of the Republic of Indonesia, the Village has evolved in various forms that need to be protected and empowered in order to be powerful, advanced,
} 
The awareness is implicated to the local governance in particular village governance that allow the diversity between one village to another, both with regard to terminology associated with the village and the village of institutional governance ${ }^{27}$.

Another difference also can be seen on the basis of differences in principles of village autonomy. If the Law No. 5Year 1979does not recognize the principle of admission as one of the principles in governance of the village, Law No. 6, 2014 lays down the principle of admission on the first list of principles that should be adopted for governance of village. The implications of the recognition of the admission principle is the recognition of the right of the origin and customs as instruments attach and determines the extent of autonomy from one village to another ${ }^{28}$.

The development of thinking on the concept of unitary state that is decentralized, relying on the protection of human rights has been implicated to the regulatory purposes in the village of Law No.. 6, 2014 that the emphasis is no longer effective and efficient. It is rather to attempt ensuring the clarity of the existence of the village as a unit of community, preserving and encouraging the local wisdom that growing in rural communities so its instrument could improve the quality of village people's life. ${ }^{29}$ The success of the state in managing the region is no longer on the strength of the territorial integrity and effectiveness of administrative procedures, but rather it is the inner and outer well-being that comes from existential consciousness as a soziocultural entity.

\section{Conceptual Construction.}

The formar term of juridical autonomy of the village first appeared in General Explanation of District Law No. 76, 2001 on Pedoman Umum Pengaturan Mengenai Desa, that afterwards is shifted back to the General Explanation of District Law No. 72, 2005 about village. ${ }^{30}$ As in the previous discussion, the concept cannot be found textually neither in the articles and article elucidations of of Village Law nor in Law No. 6, 2014. The concept of village autonomy in the previous discussion is the result of reconstruction of a series of local governance policies that put the village as one of its parts, so to understand the concept of village autonomy in both these laws, it should be examined as a whole conceptual edifice of regional autonomy contained in the regional autonomy law as lexgenerally of legislation village.

The absence of raw concept of village autonomy in Law No.5Year 1979is understandable, remembering the philosophical construction of the law requires local governance and the village is done centralistic with strict limitation. However, the absence of these conceptions contained in Law No. 6, 2014 is very surprising, remembering that the concept of village autonomy has been raised at the previouslyon Village Law. This can be interpreted as a form of setbacks in village governance in thereform period, because there is the impression of

\footnotetext{
independent, and democratic so as to create a solid foundation in implementing governance and development towards a just, prosperous, and prosper"

${ }^{27}$ Article 1 paragraph 1: "The village is a village and rural custom, afterwards, it is called Village which is a legal community unit that has borders with the authority to regulate and govern their activity, the interests of the local community based community initiatives, the right origin and / or customary rights recognized and respected through the governance system of the Republic of Indonesia."

${ }^{28}$ Indonesia, Law No. 6 Year 2014 on Village.Article 3.

${ }^{29}$ Ibid.Article 4.

${ }^{30}$ The General Explanation ofIndonesia, Government Regulation Number 72 Year 2005, 2005.: "the autonomy of the villages that is right, power and obligation to regulate and manage their own affairs and interests of society based on rights origins and values of society and culture that exist in local communities are given the opportunity to grow and develop, following the development of their own village".
} 
the relationship of power that tends to be drawn towards. On the other hand, such condition can be interpreted as a form of correction for the failure of previous legislation regimeto boost the effectiveness and efficiency of regional development and management.

Construction of village autonomy in Law No. 5Year 1979as well as in Law No. 6, 2014 is conceptually the same or rather it doesn't have significant conceptual differences. Because the concept of village autonomy in both laws formulated as a set of rights, obligations and responsibilities for the management of domestic affairs of the village (including government affairs and social) by the village government structure. Spirit arrangements underlying the legislation is reflectively the same such as trying to restore local governance to their identity as part of the governance of the unitary state of Indonesia. ${ }^{31}$

The difference can be seen through these two exist concepts on the clarity of the substance of village autonomy that the formulation of the Law No. 5Year 1979is not explained in the realm of village autonomy. So, there is an impression that the village is not autonomous in domestic affairs of governing the village, although the true rights, powers and responsibilities of the village is recognized by the state through the mechanism of decentralization, and recognition of the position of the Chief of Village as a representation of the village. The Law No. 6, 2014 explicitly formulate instruments village autonomy in some matters, which are described in a limited manner in the 1945 Indonesia Constitution, as well as in Government Regulation Number. 43, 2014 concerning the Implementing Regulations of Village Law.

Another substantive differences can also be overseen from the pattern of the village and the traditional village setting. Law No. 5Year 1979does not explicitly parting the concept of village that is set as a village customs and as a part of the socio-cultural construction, while Law No. 6, 2014 separates the dichotomous concept of the village and village customs. The substantial differences of the two patterns lie in the differentiation concept of village autonomy in rural and customary villages in Law No. $6,2014^{32}$ that is not finished by the new order with the monocultural policy.

\section{Capacity Scope of Autonomy}

The difference between the construction of village autonomy Law No. 5Year 1979and Law No. 6, 2014 can be seen distinctively when we examine the scope of village autonomy in the relation of the rights, powers and responsibilities which attach to the village. As previously discussed, that in the Law No. 6, 2014 explicitly stated the scope of authority, rights and duties of village and rural communities in detail.Whereasin Law No. 5, 1979, There is no textual affirmation both in the formulation of article-by-article and explanation of these laws and their implementing regulations concerning authority, rights and obligations of the village.

The existence of strict rules in Law No. 5Year 1979does not change the village fully autonomous for governing their domestic affairs. Because in addition to limited government affairs and public affairs that authorized by the Chief of the village, the legislation does not open up spaces for the village to develop the autonomy and their potential independently. Centralization of village governance in the hands of Chief of Village is also effective to support the centralization of state power because government can easily control the policy direction of

\footnotetext{
${ }^{31}$ Same perspective in JimlyAsshiddiqie: Asshiddiqie, Gagasan Konstitusi Sosial: Institusionalisasi Dan Konstitusionalisasi Kehidupan Sosial Masyarakat Madani, p. 367.

${ }^{32}$ Status and position of different organizations make rural and Customary villages also have different scope of authority. Differences authority and rights of rural and customary village can be seen in Article 34 and Article 35 of the Indonesia, Law No. 6 Year 2014 on Village..
} 
the village through the village head who is hierarchical seated as the representative of the central government.

Different conditions can be overseen on Law No.. 6, 2014 which expressly establishes the scope of village autonomy. The affirmation of the scope of village autonomy in the form of authority, rights and responsibilities of the Village and the Village Community is able to give comfort to the village government and its people in government and develop the potential that exists in the village ${ }^{33}$. Expansion of rural financial resources substantively distinguish the scope of authority of the village in this law which can stimulate the development of public facilities and infrastructure in the countryside. The participatory approach with the involvement of village stakeholders, from planning to the utilization of the funds of the village. is an important part of the spirit of democratization and autonomy of villagers being taken by this law.

The most striking difference of Law No.. 6, 2014 besides the addition of financial resources of the village is a guarantee of the existence of Village Custom's through affirmation scope of authority of the minimum that should be on the entity of Village Customs, including authority over the governance and wealth of the village, the management authority of the management of people's lives based on customary law, and the determination of the term of office of the head indigenous villages. Another difference of the two laws is the perception of the position of village head. If in Law No. 51979 Village Head is a representation of village autonomy attached to her village, then in Law No. 6, 2014 the village head is not completely put as a representative (government) village, but only represents the village government institutions, so that the authority, rights and duties of village head only covers government affairs of the village.

\section{Conclusion}

Law No.. 6, 2014 does not explicitly provide a definition of village autonomy. Nevertheless, the conceptual edifice of village autonomy can be examined by reconstructing the conceptual position in the village of local governance. From the following results of reconstruction, it could be concluded that the autonomy of the village is a set of rights, obligations and responsibilities for the management of the village activities (including government affairs and social) in the village government structure or owned by the village as an autonomous region.

The construction of village autonomy between the Law No. 6 Year 2014 and Village Law actually do not have a very significant difference, remembering the spirit promoted by the two laws is almost the same. In one case it regulates the existence of the village and on the other hand strengthens the construction of the Homeland. Nevertheless, improvements done in the draft of Law No. 6, 2014 by increasing the funding source for the village, and guarantee the right to determine her village. A village, in Law No. 6, 2014, is possible to switch into a village custom, a policy that even listed in Law No. 32, 2004, and the Government Regulation No. 72 Year 2005 does not exist.

Generally, the construction of village autonomy in Law No.. 5, 2014 is response to the demands of improving the fate of the village. Nevertheless, it needs to be considered applying a clear framework of autonomy for the village and village custom, since their characteristics and existence are no longer the same. Equating the treatments and approaches of the village custom

\footnotetext{
${ }^{33}$ Related to the scope of authority, the rights and obligations of the village and the village custom, see: Indonesia, Government Regulation Number 43 Year 2014, 2014. Jo Indonesia, Governemnt Regulation Number 47 2015 Concerning the Implementation Regulations of Village Law, 2015..
} 
with a village-based approach could end in the traditional village character assassination. Thus, we need the affirmation of the traditional village status and limitations of state intervention on traditional village.

The addition of village funding source from state budget is a significant advancement that produced by the enactment of Law No. 6, 2014, compared with the previous Village Law. However, caution is warranted that such funding be administratively cannot be reserved for village customs, considering the position and the characteristics and capacities of the traditional village itself. In this context, the government should prepare a package of preferential policies to accommodate the needs of funding for village custom by relying on the identity and capacity of village custom which is a self governing community. 


\section{Bibliography}

Asshiddiqie, Jimly. Gagasan Konstitusi Sosial: Institusionalisasi Dan Konstitusionalisasi Kehidupan Sosial Masyarakat Madani. 1st ed. Jakarta: LP3ES, 2015.

. "Konstitusi Masyarakat Desa (Piagam Tanggung Jawab Dan Hak Asasi Warga Desa).” Jakarta, 2015.

Huda, Ni'matul. Hukum Pemerintahan Desa Dalam Konstitusi Indonesia Sejak Kemerdekaan Hingga Era Reformasi. 1st ed. Malang: Setara Press, 2015.

Indonesia. Governemnt Regulation Number 472015 Concerning the Implementation Regulations of Village Law, 2015.

—. Government Regulation Number 43 Year 2014, 2014.

_. Government Regulation Number 72 Year 2005, 2005.

—. Law Number 5 Year 1974, 1974.

—. Law Number 5 Year 1979 on Village Government, 1979.

- Law of the Republic of Indonesia Number 6 Of 2014. https://www.kemenkeu.go.id/en/Peraturan/law-republic-indonesia-number-6-2014, n.d.

_. Undang-Undang Dasar Negara Kesatuan Republik Indonesia Tahun 1945. The 1945 Constitution of The State of Republic of Indonesia: Unofficial Translation, 1945.

—. UU Nomor 6 Tahun 2014 Tentang Desa. Law Number 6: SG No. 7, 2014.

“Kades Desak Alokasi APBN Untuk Desa Segera Disahkan.” Www. Jppn.com, 2013. http://www.jpnn.com/read/2013/12/18/206361/Kades-Desak-Alokasi-APBN-Untuk-Desa-segeraDisahkan-.

Kartohadikoesoemo, Soetardjo. Desa. 1st ed. Jakarta: Balai Pustaka, 1984.

Nurcholis, Hanif. Pertumbuhan Dan Penyelenggaraan Pemerintahan Desa. Jakarta: Penerbit Erlangga, 2011.

Sujatmoko, Emanuel. “Pembagian Kekuasaan Secara Vertikal.” Yuridika 20, no. 1 (2005).

Suryaningrat, Bayu. Pemerintahan Administrasi Desa Dan Kelurahan. 4th ed. Jakarta: Rineka Cipta, 1992. 